\title{
Meta-evaluation in Primary Health Care Evaluative Studies: a Scoping Review
}

Osvaldo de Goes Bay Junior ( $\sim$ osvaldobay_jr@hotmail.com )

Universidade Federal do Rio Grande do Norte https://orcid.org/0000-0002-1017-2346

Cícera Renata Diniz Vieira Silva

Universidade Federal do Rio Grande do Norte

\section{Rayssa Horácio Lopes}

Universidade Federal do Rio Grande do Norte

Cláudia dos Santos Martiniano

Universidade Estadual da Paraiba

Miguel Fuentealba-Torres

Universidad de Los Andes

Ricardo Alexandre Arcêncio

Universidade de Sao Paulo Escola de Enfermagem de Ribeirao Preto

Severina Alice da Costa Uchôa

Universidade Federal do Rio Grande do Norte

\section{Research Article}

Keywords: Primary Health Care, Health Evaluation, Meta-evaluation, Evaluation Studies as Topic, Review Literature as Topic

Posted Date: January 28th, 2022

DOI: https://doi.org/10.21203/rs.3.rs-1282037/v1

License: (c) (i) This work is licensed under a Creative Commons Attribution 4.0 International License.

Read Full License 


\section{Abstract}

Background: The evaluation of health policies and programs expanded in both practical and theoreticalmethodological fields, with a strong influence on health system quality, decisions of managers, sustainability, and improvement of the primary care services. However, guaranteeing the qualification and credibility of the evaluation processes using meta-evaluations is a huge challenge for evaluators. This review aimed to map meta-evaluation use in Primary Health Care evaluative studies.

Methods: We conducted a scoping review based on the Joanna Briggs Institute manual and guided by PRISMA Extension for Scoping Reviews (PRISMA-ScR). A systematic and comprehensive three-step search was performed in January and February 2021 in multidisciplinary health science databases and gray literature. No limits concerning publication dates were set. Data extraction and eligibility were performed by two independent authors and interpreted using thematic analysis. The themes were collated, and a narrative summary of the findings reported.

Results: There were 11,641 potential studies identified from the search, finally, 23 studies were included in the analysis. Four thematic groups were identified: search results; characteristics of the included studies; meta- evaluation type, involved stakeholders, and Evaluative standards applied; potentialities and challenges in the meta-evaluation primary health care. Most were summative meta-evaluations focusing on health programs and primary care management and followed the quality standards of the Joint Committee on Standards for Educational Evaluation. We observed low involvement of service users and active participation of managers, health professionals, researchers like stakeholders. We also highlight the importance of formative and democratic meta-evaluations expanding the use of evaluations.

Conclusion: Results showed the potential and challenges of using meta-evaluation in primary health care during or when the evaluations have been completed. Highlighted the importance of permanent and systematic analysis of the quality of evaluations. Meta-evaluators have the technical responsibility of the evaluation process, stimulus to the action of those involved, and decision-making capacity. There is a paucity of published literature on meta-evaluation in primary health care. Hence, further studies are recommended to qualify the processes and results of the evaluations capable of contributing to the improvement and qualification of public policies and health practices.

\section{Background}

The World Health Organization, according to the 2030 Agenda for Sustainable Development, reaffirms protagonism of the Primary Health Care (PHC) to ensure healthcare system sustainability $[1,2]$. This model influenced sanitary changes in countries with public and universal health systems, occupied a prominent place in international policy agendas [3], and expanded offer and service availability, influencing positively in population health [4].

The debate regarding health system quality and role of managers in decisions is becoming urgent, generating a consensus about the need for technical evaluations. Furthermore, evaluation of health 
programs expanded in both practical and theoretical-methodological fields [5]. Studies also reported the importance of PHC evaluative experiences to sustainability and service quality improvement $[6,7,8]$.

Although evaluation results are significant, the search for qualification of evaluative processes must be considered to increase credibility. According to Jacob and Affodegon [9], evaluation is the search for continuous improvement while evaluators consult instruments to guarantee validity of conclusions and recommendations.

Meta-evaluations assess quality of evaluations $[10,11]$ through description, judgment, and synthesis processes based on criteria and validated by associations and auditing authorities [12]. It promotes quality of evaluated interventions, operationalizes interests, and offers subsidies to evaluative improvements [13].

Evaluative researches in PHC increased [14, 15, 16, 17], drawing attention to development of metaevaluation studies. This review will provide information synthesis, which may guide meta-evaluation activities and other researches and evaluative practices. Therefore, the present review aimed to map meta-evaluation use in PHC evaluative studies. We considered the identification of meta-evaluation types, objects, criteria or applied evaluations, involvement of stakeholders, and learned lessons.

\section{Method}

This scoping review was conducted based on the Joanna Briggs Institute (JBI) manual [18], and guided by the PRISMA Extension for Scoping Reviews (PRISMA-ScR) [19]. We also followed the steps proposed by Arksey and O'Malley [20] and Levac et al. [21]: formulation of research question; identifying relevant studies; study selection; data extraction and coding; collating, summarizing, reporting, and discussing results; and stakeholder consultation.

The study was approved by research ethics committee of Onofre Lopes University Hospital - Federal University of Rio Grande do Norte (CAAE: 84537418.1.0000.5292)., and direct participation of people in the study occurred only during consultation with stakeholders. The methodology used was previously reported in a protocol registered in Figshare [22].

\section{Formulation of research question}

Study question was defined by consensus among authors and formulated using PCC mnemonic (Population, Concept, and Context) [18]: How meta-evaluation is being used in PHC evaluative studies?

\section{Identifying relevant studies}

We observed a lack of reviews regarding the topic after consulting JBI Evidence Synthesis, Cochrane Database of Systematic Reviews, and Campbell Library. Researchers specialized in bibliographic search developed the initial search strategy, and the standard strategy was developed after a pilot search. Descriptors were chosen according to Medical Subject Headings (MeSH) and Health Sciences Descriptors 
(DeCS), combining keywords and Boolean operators 'AND' and 'OR' to contemplate PCC mnemonic terms. Additional file 1 presents the strategy performed in each database.

The following multidisciplinary health science databases were used: MEDLINE/PubMed, Scopus, Web of Science, Virtual Health Library, and Scientific Electronic Library Online (SciELO). Grey literature was identified in international repositories from Europe (DART-Europe E-Theses Portal, Repositórios Científicos de Acesso Aberto de Portugal [RCAAP], and Electronic Theses Online Service [EthOS]), Africa (National ETD Portal South African Theses and dissertations), North America (Theses Canada - Library and Archives Canada), and South America (Catálogo de Teses e Dissertações da Coordenação de Aperfeiçoamento de Pessoal de Nível Superior [CAPES]). Google Scholar and reference lists of identified studies were also consulted for grey literature.

\section{Study selection}

Searches were performed between January 21 and February 12, 2021, using a three-step search strategy [8]: 1. Identification of descriptors and keywords, with an initial exploratory search in two databases, followed by the construction of the search strategy; 2 . Definition and search across all databases; 3 . Search for additional sources in the selected publications references. Search strategies are presented in additional file 1.

Study selection followed the Preferred Reporting Items for Systematic Review and Meta-Analyses (PRISMA-P) [23]: identification, screening, eligibility, and inclusion.

Mendeley software was used for identification, management, and organization, and duplicates were removed. The second step screened potentially relevant studies through the extensive title and abstract reading by two independent reviewers (OGBJ and CRDVS). Eligibility was performed through full-text reading by two independent reviewers. In case of disagreement, a third reviewer (SACU) was consulted.

Eligibility criteria included PHC meta-evaluation studies (quantitative and qualitative, regardless of method used); theses and dissertations (grey literature); electronically available in Portuguese, Spanish, or English languages; in accordance with research question; and from inception to February 2021; Primary studies not involving meta-evaluation, literature reviews, theoretical essays, specialist opinions, manuals, and books were excluded.

\section{Data extraction and coding}

Data were extracted and encoded using a form based on JBI template [18] and adapted by authors, containing the following information: characterization of studies (first author, publication year, country of origin, aim, and study design); meta- evaluation type, involved stakeholders, and Evaluative standards applied; potentialities and challenges in the meta-evaluation primary health care. Data extraction form are presented in additional file 2 .

\section{Collating, summarizing, reporting, and discussing results}


Narrative analysis and absolute ad relative frequencies of year, country, aim, design, and meta-evaluation type were performed. Narrative synthesis regarding evaluation criteria or standard, involvement of stakeholders, meta-evaluation objects, and learned lessons were performed using thematic analysis [24]. Results were reported as narrative presentations, boxes, and figures to facilitate information synthesis.

\section{Stakeholder consultation}

Results of this review were presented to four stakeholders (i.e., researchers with experience in PHC metaevaluation) to fulfill the following objectives recommended by Levac et al. [21]: preliminary sharing of study findings (i.e., knowledge transfer and exchange mechanism) and development of effective dissemination strategies and ideas for future studies.

\section{Result}

In all, 11,553 articles and 88 dissertations and theses., were obtained from all databases during the initial search, of which 6,598 titles met the eligibility criteria at the title screening stage. A total of 21 titles were identified as duplicates and removed using Mendeley Desktop. After eligibility criteria, exclusion of duplicates, analysis of titles and abstracts, and full-text reading, in two consecutive assessments, 23 publications were included for data extraction in this review (Fig. 1). All the included studies somehow demonstrated the uses of meta-evaluation in the evaluative studies developed in the PHC.

Fig. 1 - Flowchart of study selection process for scoping review adapted from Preferred Reporting Items for Systematic Review and Meta-Analyses (PRISMA-P).

\section{Characteristics of the included studies}

A total of 14 studies were conducted in Brazil $[26,27,29,31,33,34,37,39,40,41,42,45,46,47], 3$ studies in United States [25, 32, 44], 3 studies in Canada [30, 35, 36], 1 study in United Kingdom [28], 1 study in Guine-Bissau [43], and 1 study in Australia [38] (Fig. 2).

Fig. 2 - Quantitative geographic distribution of included studies.

Most studies were published in 2018, followed by 2012, 2015, and 2017 (60.9\% of publications). We identified the following meta-evaluation objects (i.e., evaluations assessed): Family Health Strategy [26, 27, 42, 46]; external evaluation of the National Program for Access and Quality Improvement in Primary Care $\{P M A Q-A B)[37,39,45]$; health management [33, 40, 41]; children health [25, 28, 32]; tuberculosis [29, 47]; health of rural women [38]; mental health [34]; guideline and prescription of drugs [36]; International Healthy Cities Movement [31]; health development [43]; assistance development [44]; professional capacitation [30]; and primary care projects [35]. Most meta-evaluations were qualitative (56.5\%). Document analysis was the most used technique (69.6\%), and questionnaires, interviews, focus groups, workshops, and observations were also mentioned (Table 1).

Table 1 - Characteristics of the included studies between 1999 and $2018(N=23)$. 
From: Meta-evaluation in primary health care evaluative studies: a scoping review 


\begin{tabular}{|c|c|c|c|c|}
\hline $\begin{array}{l}\text { Author } \\
\text { and year }\end{array}$ & Type & Country & Meta-evaluation objectives & $\begin{array}{l}\text { Methodological } \\
\text { aspects }\end{array}$ \\
\hline \multirow{2}{*}{$\begin{array}{l}\text { Sanders, } \\
\text { J.R. } 1999 \\
\text { [25] }\end{array}$} & \multirow[t]{2}{*}{ Article } & \multirow[t]{2}{*}{ USA } & \multirow[t]{2}{*}{$\begin{array}{l}\text { National evaluative study of an infant } \\
\text { development program }\end{array}$} & $\begin{array}{l}\text { Qualitative } \\
\text { approach; }\end{array}$ \\
\hline & & & & $\begin{array}{l}\text { Document } \\
\text { analysis. }\end{array}$ \\
\hline \multirow[t]{4}{*}{$\begin{array}{l}\text { Fonseca, } \\
\text { A.C.F. } \\
2009[26]\end{array}$} & \multirow[t]{4}{*}{ Dissertation } & \multirow[t]{4}{*}{ Brazil } & \multirow[t]{4}{*}{$\begin{array}{l}\text { Evaluative practices of Evaluation for } \\
\text { Quality Improvement in Family Health } \\
\text { Strategy }\end{array}$} & $\begin{array}{l}\text { Qualitative } \\
\text { approach; }\end{array}$ \\
\hline & & & & Case study; \\
\hline & & & & $\begin{array}{l}\text { Document } \\
\text { analysis; }\end{array}$ \\
\hline & & & & Interviews. \\
\hline \multirow[t]{2}{*}{$\begin{array}{l}\text { Figueiró, } \\
\text { A.C. } \\
2010[27]\end{array}$} & \multirow[t]{2}{*}{ Article } & \multirow[t]{2}{*}{ Brazil } & \multirow[t]{2}{*}{$\begin{array}{l}\text { Evaluative report of baseline studies of } \\
\text { the Brazilian Family Health Strategy } \\
\text { Expansion Project }\end{array}$} & $\begin{array}{l}\text { Quanti- } \\
\text { qualitative } \\
\text { approach; }\end{array}$ \\
\hline & & & & $\begin{array}{l}\text { Document } \\
\text { analysis. }\end{array}$ \\
\hline \multirow{2}{*}{$\begin{array}{l}\text { Léveillé, } \\
\text { S. } 2010 \\
\text { [28] }\end{array}$} & \multirow[t]{2}{*}{ Article } & \multirow[t]{2}{*}{$\begin{array}{l}\text { United } \\
\text { Kingdom }\end{array}$} & \multirow{2}{*}{$\begin{array}{l}\text { Evaluation studies of action model } \\
\text { implementation for vulnerable children } \\
\text { and their families }\end{array}$} & $\begin{array}{l}\text { Quantitative } \\
\text { approach; }\end{array}$ \\
\hline & & & & $\begin{array}{l}\text { Document } \\
\text { analysis. }\end{array}$ \\
\hline \multirow[t]{3}{*}{$\begin{array}{l}\text { Natal, S. } \\
2012[29]\end{array}$} & \multirow[t]{3}{*}{ Article } & \multirow[t]{3}{*}{ Brazil } & \multirow[t]{3}{*}{$\begin{array}{l}\text { Evaluative process of research projects } \\
\text { supported by the Global Fund } \\
\text { Tuberculosis Project in Brazil }\end{array}$} & $\begin{array}{l}\text { Qualitative } \\
\text { approach; }\end{array}$ \\
\hline & & & & $\begin{array}{l}\text { Document } \\
\text { analysis; }\end{array}$ \\
\hline & & & & Interviews. \\
\hline \multirow[t]{5}{*}{$\begin{array}{l}\text { Dickson, } \\
\text { R. } 2012 \\
\text { [30] }\end{array}$} & \multirow[t]{5}{*}{ Thesis } & \multirow[t]{5}{*}{ Canada } & \multirow[t]{5}{*}{$\begin{array}{l}\text { Evaluation of a continuous professional } \\
\text { development program for health } \\
\text { professionals }\end{array}$} & $\begin{array}{l}\text { Quanti- } \\
\text { qualitative } \\
\text { approach; }\end{array}$ \\
\hline & & & & Case study; \\
\hline & & & & $\begin{array}{l}\text { Document } \\
\text { analysis; }\end{array}$ \\
\hline & & & & Interviews; \\
\hline & & & & Focus groups. \\
\hline \multirow[t]{2}{*}{$\begin{array}{l}\text { Dias, } \\
\text { A.L.F. } \\
2012[31]\end{array}$} & \multirow[t]{2}{*}{ Thesis } & \multirow[t]{2}{*}{ Brazil } & \multirow[t]{2}{*}{$\begin{array}{l}\text { Evaluative studies in the context of } \\
\text { International Healthy Cities Movement }\end{array}$} & $\begin{array}{l}\text { Quanti- } \\
\text { qualitative } \\
\text { approach; }\end{array}$ \\
\hline & & & & $\begin{array}{l}\text { Document } \\
\text { analysis. }\end{array}$ \\
\hline
\end{tabular}




\begin{tabular}{|c|c|c|c|c|}
\hline $\begin{array}{l}\text { Author } \\
\text { and year }\end{array}$ & Type & Country & Meta-evaluation objectives & $\begin{array}{l}\text { Methodological } \\
\text { aspects }\end{array}$ \\
\hline \multirow{2}{*}{$\begin{array}{l}\text { Nkwake, } \\
\text { A.M. } \\
2013 \text { [32] }\end{array}$} & \multirow[t]{2}{*}{ Article } & \multirow[t]{2}{*}{ USA } & \multirow[t]{2}{*}{$\begin{array}{l}\text { Evaluation results from child well-being } \\
\text { programs }\end{array}$} & $\begin{array}{l}\text { Quantitative } \\
\text { approach; }\end{array}$ \\
\hline & & & & $\begin{array}{l}\text { Document } \\
\text { analysis. }\end{array}$ \\
\hline \multirow[t]{3}{*}{$\begin{array}{l}\text { Nickel, } \\
\text { D.A. } \\
2014 \text { [33] }\end{array}$} & \multirow[t]{3}{*}{ Article } & \multirow[t]{3}{*}{ Brazil } & \multirow[t]{3}{*}{$\begin{array}{l}\text { Evaluation of the primary care State } \\
\text { management focused on strengthening } \\
\text { evaluation and monitoring }\end{array}$} & $\begin{array}{l}\text { Qualitative } \\
\text { approach; }\end{array}$ \\
\hline & & & & Case study; \\
\hline & & & & Interviews. \\
\hline \multirow[t]{4}{*}{$\begin{array}{l}\text { Furtado, } \\
\text { J.P. 2014 } \\
\text { [34] }\end{array}$} & \multirow[t]{4}{*}{ Article } & \multirow[t]{4}{*}{ Brazil } & \multirow{4}{*}{$\begin{array}{l}\text { Evaluative process about home of people } \\
\text { with severe mental disorders in the } \\
\text { context of Brazilian psychiatric } \\
\text { deinstitutionalization }\end{array}$} & $\begin{array}{l}\text { Qualitative } \\
\text { approach; }\end{array}$ \\
\hline & & & & Interviews; \\
\hline & & & & Focus Groups; \\
\hline & & & & $\begin{array}{l}\text { Participant } \\
\text { observation. }\end{array}$ \\
\hline \multirow[t]{3}{*}{$\begin{array}{l}\text { Webster, } \\
\text { F. 2015 } \\
\text { [35] }\end{array}$} & \multirow[t]{3}{*}{ Article } & \multirow[t]{3}{*}{ Canada } & \multirow{3}{*}{$\begin{array}{l}\text { Evaluative projects of health } \\
\text { interventions based on primary, hospital, } \\
\text { and community care }\end{array}$} & $\begin{array}{l}\text { Qualitative } \\
\text { approach; }\end{array}$ \\
\hline & & & & $\begin{array}{l}\text { Document } \\
\text { Analysis; }\end{array}$ \\
\hline & & & & Interviews. \\
\hline \multirow[t]{4}{*}{$\begin{array}{l}\text { Conklin, } \\
\text { J. } 2015 \\
\text { [36] }\end{array}$} & \multirow[t]{4}{*}{ Article } & \multirow[t]{4}{*}{ Canada } & \multirow[t]{4}{*}{$\begin{array}{l}\text { Evaluation of drug prescriptions } \\
\text { guidelines }\end{array}$} & $\begin{array}{l}\text { Quanti- } \\
\text { qualitative } \\
\text { approach; }\end{array}$ \\
\hline & & & & $\begin{array}{l}\text { Document } \\
\text { analysis; }\end{array}$ \\
\hline & & & & Interviews; \\
\hline & & & & Observation. \\
\hline \multirow[t]{3}{*}{$\begin{array}{l}\text { Santos, } \\
\text { P.F. 2015 } \\
\text { [37] }\end{array}$} & \multirow[t]{3}{*}{ Dissertation } & \multirow[t]{3}{*}{ Brazil } & \multirow[t]{3}{*}{$\begin{array}{l}\text { External evaluation of the National } \\
\text { Program for Improving Access and } \\
\text { Quality of Primary Care }\end{array}$} & $\begin{array}{l}\text { Quantitative } \\
\text { approach; }\end{array}$ \\
\hline & & & & $\begin{array}{l}\text { Document } \\
\text { analysis; }\end{array}$ \\
\hline & & & & Questionnaires. \\
\hline
\end{tabular}




\begin{tabular}{|c|c|c|c|c|}
\hline $\begin{array}{l}\text { Author } \\
\text { and year }\end{array}$ & Type & Country & Meta-evaluation objectives & $\begin{array}{l}\text { Methodological } \\
\text { aspects }\end{array}$ \\
\hline \multirow[t]{3}{*}{$\begin{array}{l}\text { Kozica, } \\
\text { S.L. } 2016 \\
\text { [38] }\end{array}$} & \multirow[t]{3}{*}{ Article } & \multirow[t]{3}{*}{ Australia } & \multirow[t]{3}{*}{$\begin{array}{l}\text { Evaluation of a healthy lifestyle program } \\
\text { for rural women }\end{array}$} & $\begin{array}{l}\text { Quanti- } \\
\text { qualitative } \\
\text { approach; }\end{array}$ \\
\hline & & & & Interviews; \\
\hline & & & & Questionnaires. \\
\hline \multirow[t]{2}{*}{$\begin{array}{l}\text { Folli, } \\
\text { S.P.L. } \\
2016[39]\end{array}$} & \multirow[t]{2}{*}{ Dissertation } & \multirow[t]{2}{*}{ Brazil } & \multirow[t]{2}{*}{$\begin{array}{l}\text { External evaluation of the National } \\
\text { Program for Improving Access and } \\
\text { Quality of Primary Care }\end{array}$} & $\begin{array}{l}\text { Qualitative } \\
\text { approach; }\end{array}$ \\
\hline & & & & Interviews. \\
\hline \multirow[t]{3}{*}{$\begin{array}{l}\text { Almeida, } \\
\text { C.A.L. } \\
2017[40]\end{array}$} & \multirow[t]{3}{*}{ Article } & \multirow[t]{3}{*}{ Brazil } & \multirow[t]{3}{*}{$\begin{array}{l}\text { An experience of participative evaluation } \\
\text { developed by municipal health } \\
\text { secretaries and accessors }\end{array}$} & $\begin{array}{l}\text { Qualitative } \\
\text { approach; }\end{array}$ \\
\hline & & & & Interviews; \\
\hline & & & & Workshops. \\
\hline \multirow[t]{3}{*}{$\begin{array}{l}\text { Almeida, } \\
\text { C.A.L. } \\
2017[41]\end{array}$} & \multirow[t]{3}{*}{ Article } & \multirow[t]{3}{*}{ Brazil } & \multirow[t]{3}{*}{$\begin{array}{l}\text { Participative evaluation performed by } \\
\text { municipal representatives of a health } \\
\text { sector }\end{array}$} & $\begin{array}{l}\text { Qualitative } \\
\text { approach; }\end{array}$ \\
\hline & & & & Interviews; \\
\hline & & & & Workshops \\
\hline \multirow[t]{4}{*}{$\begin{array}{l}\text { Oliveira, } \\
\text { M.R. } \\
2017 \text { [42] }\end{array}$} & \multirow[t]{4}{*}{ Dissertation } & \multirow[t]{4}{*}{ Brazil } & \multirow{4}{*}{$\begin{array}{l}\text { One of the evaluation fields (Family } \\
\text { Health Strategy) instituted by the } \\
\text { Comptroller General of the Union, entitled } \\
\text { Evaluation of Government Programs } \\
\text { Execution }\end{array}$} & $\begin{array}{l}\text { Quanti- } \\
\text { qualitative } \\
\text { approach; }\end{array}$ \\
\hline & & & & $\begin{array}{l}\text { Document } \\
\text { Analysis; }\end{array}$ \\
\hline & & & & Questionnaires; \\
\hline & & & & Interviews. \\
\hline \multirow{3}{*}{$\begin{array}{l}\text { Guerreiro, } \\
\text { C.S. } \\
2018[43]\end{array}$} & \multirow[t]{3}{*}{ Article } & \multirow[t]{3}{*}{$\begin{array}{l}\text { Guine- } \\
\text { Bissau }\end{array}$} & \multirow[t]{3}{*}{$\begin{array}{l}\text { Evaluation process of the National Health } \\
\text { Development Plan implementation }\end{array}$} & $\begin{array}{l}\text { Qualitative } \\
\text { approach; }\end{array}$ \\
\hline & & & & $\begin{array}{l}\text { Document } \\
\text { analysis; }\end{array}$ \\
\hline & & & & Interviews. \\
\hline \multirow[t]{2}{*}{$\begin{array}{l}\text { Raifman, } \\
\text { J. } 2018 \\
\text { [44] }\end{array}$} & \multirow[t]{2}{*}{ Article } & \multirow[t]{2}{*}{ USA } & \multirow[t]{2}{*}{$\begin{array}{l}\text { Evaluation of the Assistance } \\
\text { Development ordered or conducted by } \\
\text { main global health financiers }\end{array}$} & $\begin{array}{l}\text { Quantitative } \\
\text { approach; }\end{array}$ \\
\hline & & & & $\begin{array}{l}\text { Document } \\
\text { analysis. }\end{array}$ \\
\hline
\end{tabular}




\begin{tabular}{|c|c|c|c|c|}
\hline $\begin{array}{l}\text { Author } \\
\text { and year }\end{array}$ & Type & Country & Meta-evaluation objectives & $\begin{array}{l}\text { Methodological } \\
\text { aspects }\end{array}$ \\
\hline \multirow[t]{3}{*}{$\begin{array}{l}\text { Uchoa, } \\
\text { S.A.C. } \\
2018[45]\end{array}$} & \multirow[t]{3}{*}{ Article } & \multirow[t]{3}{*}{ Brazil } & \multirow[t]{3}{*}{$\begin{array}{l}\text { External evaluation of the National } \\
\text { Program for Improving Access and } \\
\text { Quality of Primary Care }\end{array}$} & $\begin{array}{l}\text { Qualitative } \\
\text { approach; }\end{array}$ \\
\hline & & & & Interviews; \\
\hline & & & & Focus groups. \\
\hline \multirow{2}{*}{$\begin{array}{l}\text { Barros, } \\
\text { L.F.R. } \\
2018[46]\end{array}$} & \multirow[t]{2}{*}{ Article } & \multirow[t]{2}{*}{ Brazil } & \multirow[t]{2}{*}{$\begin{array}{l}\text { Evaluation report of Govern programs } \\
\text { execution n.8: Family Health Programme }\end{array}$} & $\begin{array}{l}\text { Qualitative } \\
\text { approach; }\end{array}$ \\
\hline & & & & $\begin{array}{l}\text { Document } \\
\text { analysis }\end{array}$ \\
\hline \multirow{5}{*}{$\begin{array}{l}\text { Abreu, } \\
\text { D.M.F. } \\
2018[47]\end{array}$} & \multirow[t]{5}{*}{ Thesis } & \multirow[t]{5}{*}{ Brazil } & \multirow{5}{*}{$\begin{array}{l}\text { Evaluation of the performance of } \\
\text { National Tuberculosis Control } \\
\text { Programme }\end{array}$} & $\begin{array}{l}\text { Qualitative } \\
\text { approach; }\end{array}$ \\
\hline & & & & Case study; \\
\hline & & & & $\begin{array}{l}\text { Document } \\
\text { analysis; }\end{array}$ \\
\hline & & & & Interviews; \\
\hline & & & & $\begin{array}{l}\text { Direct } \\
\text { observation. }\end{array}$ \\
\hline
\end{tabular}

\section{Meta- evaluation type, involved stakeholders, and Evaluative standards applied}

Most meta-evaluations were summative (i.e., retrospective) (87\%). Regarding stakeholders, apart from evaluators/researchers of meta-evaluations, most individuals involved were managers and health professionals, whereas service users were little involved (Table 2).

Table 2- Meta-evaluation type and stakeholders involved.

From: Meta-evaluation in primary health care evaluative studies: a scoping review 


\begin{tabular}{|c|c|c|}
\hline MAPPED CHARACTERISTICS & & REFERENCES \\
\hline \multirow[t]{2}{*}{ META-EVALUATION TYPE } & Summative & $\begin{array}{l}{[25,26,28,30,31,32,33,34,35,37,38,39,40,41,} \\
42,43,44,45,46,47]\end{array}$ \\
\hline & Formative & {$[27,29,36]$} \\
\hline \multirow{4}{*}{$\begin{array}{l}\text { STAKEHOLDERS INVOLVED IN } \\
\text { META-EVALUATION }\end{array}$} & Managers & {$[26,30,33,38,39,40,41,42,43,45,47]$} \\
\hline & Professionals & {$[26,30,33,34,35,37,38,39,42]$} \\
\hline & Users & {$[35,38,41,42]$} \\
\hline & $\begin{array}{l}\text { Evaluators/ } \\
\text { researchers }\end{array}$ & $\begin{array}{l}{[25,26,27,28,29,30,31,32,33,34,35,36,37,38,} \\
39,40,41,42,43,44,45,46,47]\end{array}$ \\
\hline
\end{tabular}

Applied standards to meta-evaluate evaluations were extensive, especially the Joint Committee on Standards for Educational Evaluation (JCSEE) [48] recommendations: utility, viability, propriety, and accuracy (43.5\%). JCSEE utility standard was used in $26 \%$ of meta-evaluations. Table 3 demonstrates all evaluative standards mentioned in the studies.

Table 3 - Evaluative standards applied in PHC meta-evaluation.

From: Meta-evaluation in primary health care evaluative studies: a scoping review 


\section{EVALUATIVE STANDARDS}

Consistence

Validity

Inovation

Legal principles

Influence

Intencionality

Interdisciplinarity

Realistic evaluation

Materiality; Criticality

Rigor; Credibility; Confirmability; Transferability

Complementarity; Autonomy; Competence of individuals;

Evaluative Culture

Efficacy; Reach; Adoption; Implementation; Sustentability;

Adoption

Reliability

Etical Principles

Participation

Relevance

Utility (JCSEE)

Utility; Viability; Propriety; Accuracy (JCSEE)

\section{REFERENCES}

[27]

[44]

[45]

[46]

[47]

[32]

[34]

[35]

[42]

[28]

[33]

[38]

$[28,44]$

$[36,46]$

$[34,40]$

$[28,42,44,46]$

$[26,29,41,45,46,47]$

$[25,27,30,31,33,36,37,39$, $42,43]$

\section{Potentialities and challenges in PHC meta-evaluation}

The following stood out as potentialities observed in the meta-evaluation in PHC, in descending order: Pedagogical, formative, and democratic character [27, 31, 33, 35, 40, 43, 45]; Credibility of evaluation results for decision-making [25, 29, 36, 41, 44, 45, 46]; Qualification of the evaluated object [32, 33, 47]; Expand dialog between involved and interested individuals [26, 28, 29]; Formation of collaborative nets between teaching and research institutions and decision-makers [33, 45, 47]; Monitoring of financial resources application and investments viability [25, 44, 45]; Participation of individuals from different positions in the context of health system [40,44]; Generalization of results in robust meta-evaluations [38, 44]; Formative meta-evaluations allow changes during evaluation [36]; Possibility of using different 
criteria and standards [34]; Knowledge translation and health services quality improvement [36]; Scientific publication of results stimulates those involved in evaluations [29]; Potentiate results and theory of the evaluated program [32].

As for the challenges of meta-evaluation in PHC, they were identified, in descending order: Time and financial resource requirement more than the available [27, 29, 38, 44]; Adequacy of evaluation standards to political, economic, social, and cultural reality, especially in vulnerable societies [30, 40, 42, 43]; Involvement of interested parts in all steps of the evaluative process [25, 31, 41]; Negotiation and conflicts of interest mediation between actors [31, 39, 43]; Consider limitations of the evaluated object when proposing recommendations [30,47]; Ideological, political, and conjunctival factors may interfere in metaevaluation utility [26, 29]; Ethical risk in using results when meta-evaluation favors the prosecutor [41]; Use limited by reduced disclosure of results [25]; Evaluation standard used partially or randomly [42]; Some program designs difficult evaluation and meta-evaluation [38]; Participation of internal evaluators is not always viable [38]; Low credibility of evaluators among decision-makers limits the use of results [29]; Previous experiences little responsive and/or negative weaken the involvement of those interested [26]; Deal with possible consequences of major actors participation, such as conflicts [31]; Sensibilization of involved actors to actual demands of the process [31].

\section{Discussion}

Regarding PHC, evaluative studies are considered an important element to health systems reform, while international agencies suggest a broad PHC approach based on the "Renewing Primary Health Care in the Americas" document [49, 50]. In Brazil, evaluative studies were directed to PHC when this model became the focus of the health system and the first level of contact for individuals, families, and the community.

Three social and historical processes in Brazil favor meta-evaluation predominance [51]: Brazilian National Health System (SUS) organization, which formulates several sectoral policies and requires evaluation of its results; request of international funding institutions to evaluate impacts of health programs; and partnership between Brazilian Ministry of Health and Universities to evaluate policies, programs, and projects.

The predominance of publications from Brazil may be attributed to the increased number of postgraduate programs, mainly in Collective Health field, with research funding, and discussions regarding health evaluations [52]. Moreover, researchers and the Brazilian Ministry of Health enhanced evaluations methodologically and conceptually since 2000 , contributing to debates regarding the importance of evaluative cultures $[5,53]$.

Meta-evaluation studies of health programs and projects involve peculiar characteristics of health services. All studies developed in Brazil are related to PHC planning and management. Therefore, the focus reflects structural moments of PHC in this country. Among these, the following can be highlighted: 
1) Family Health Strategy growth from 2000 stimulated studies to evaluate implantation, execution, and impact of this health reorientation in the national territory $[54,55,56]$. In this perspective, we point to the Brazilian Ministry of Health initiative (supported by the World Bank), named Baseline Studies of the Project for the Expansion and Consolidation of Family Health, focused on consolidation of Family Health Strategy and primary care fortification. This project and the National Policy for the Evaluation of Primary Health Care, which tried to consolidate the institutionalization process of evaluation, were topics of evaluative studies [57].

2) PMAQ-AB creation in 2011 and increased number of studies evaluating its effects on primary care fortification, access expansion, and service quality improvement [58]. With this program, financial incentives are based on results (i.e., payment by performance), an increasing tendency in Brazil and other countries [59,60]. Moreover, external evaluation of PMAQ-AB was studied because of its detailed information and possibility of novel experiences for institutionalizing a Brazilian evaluative culture.

To Stufflebeam [10], evaluation field has advanced, especially methodologically, and evaluators should submit their evaluations to meta-evaluation. This process ensures improved efficiency and effectiveness of evaluations and provides reliable findings and conclusions of public, professional, and institutional interests.

According to the present results, methodological approaches of meta-evaluations triangulate techniques and informants within a qualitative approach, which is considered positive since it allows an overview on various dimensions and perspectives in meta-evaluative studies [61]. Methodological choice requires flexibility, creativity, and coherence with meta-evaluation object and purpose, and multiple methodological approaches are needed due to complexity of the health field [62].

Most meta-evaluation studies used the following JCSEE recommendations [48]: utility, feasibility, propriety, accuracy (precision), and responsibility $[63,64]$. These guidelines were adopted by policy and social programs (including health programs) of American and Canadian Evaluation Societies and other countries (e.g., Germany, Switzerland, Africa, and Brazil) [63].

Evaluative parameters proposed by JCSEE are relevant due to their application on the Framework for Program Evaluation in Public Health: A Checklist of Steps and Standards proposed by the Centers for Disease Control and Prevention [65]. These parameters are recommended for continuous improvement and strengthening of the cycle: Planning - Implementing - Monitoring - Evaluating $[65,66]$.

Studies suggest meta-evaluation should follow international and national standards to guide the evaluative process and assure quality [67]. However, meta-evaluation is not limited to applying criteria because they generically provide a different context according to the evaluated region.

Summative meta-evaluation was present in most studies, corroborating with Elliot and Orlando Filho [64]. This assessment is performed after evaluation to verify quality according to standards and criteria. However, formative perspective occurs during the evaluative process and guides evaluators on planning, 
conduction, improvement, interpretation, and communication [68]. Formative meta-evaluation emphasizes the learning process due to constant feedback during the evaluative process, indicating solid and weak points and guiding decisions [69].

\section{Implications for practice and research}

Most studies emphasized formative meta-evaluations approaches, their pedagogical characteristics, and the opportunity to democratize evaluations; therefore, is necessary include and increase the use of this approach, guaranteeing negotiation of interests and values of interested parties, validating them on health context especially PHC. This corroborates the assertion that when evaluation is considered an intervention that can be evaluated (e.g., meta-evaluations with scientific approaches, debates, negotiations, and learning), it stimulates changes in the reality of services to institutionalize practices and improve quality [70]. A recent movement is expanding the intention to learn with participatory, transformative, and emancipatory evaluations [71].

Expanding utility in evaluations is essential for evaluators' performance. In meta-evaluations, the term "use" is relevant in the debate about "utility" pattern [40]. Use is the evaluation outcome, an important characteristic to be considered in the evaluative process [72, 73, 74]. According to Patton [75], technical and methodological rigors are not sufficient to ensure of utility. Therefore, evaluations must respond to interests and necessities of the audience [76]. For example, different interest groups (i.e., stakeholders) can be inserted in the evaluative process [77], increasing the introduction of other groups, such as policy developers, managers, professionals, users, and clients [78].

We observed a low insertion of stakeholders in meta-evaluation, especially service users. This was found even in formative meta-evaluations where participation of stakeholders may be expanded. Metaevaluators should stimulate action of those involved and have technical responsibility in the evaluative process and decisive capacity based on results. The involvement of different stakeholders also strengthens the evaluative design and expand data collection and interpretation. This involvement increases the use of evaluation results, purpose of evaluation designs, elaboration of instruments for data collection, and results from analysis and dissemination [79, 80, 81].

Formative, pedagogical, democratic, and dialogical aspects and qualification and credibility of evaluations for decision-making are strengths of meta-evaluations. In contrast, important challenges can also be observed, such as ensuring stakeholder involvement, negotiating conflicts between them, and demand for financial resources, time, and adequacy to international evaluation standards according to reality and political, economic, social, and cultural contexts.

Our study shows limited published research on meta-evaluation of PHC, regardless the growing tendency of evaluative studies. Involvement of stakeholders was low in most meta-evaluations, indicating a gap in literature mainly among PHC users. We hope our study will stimulate research studies on formative, democratic, and participative meta-evaluations to expand the use of evaluations. We also recommend the development of more primary studies to verify quality of current or subsequent evaluations, expanding 
health evaluation credibility since there is increase in its applicability in health systems. Most of the included studies were qualitative, this demonstrates the need to develop more studies with a quantitative or mixed approach. Moreover, systematic review with meta-analysis could be performed to assess the impact of meta-evaluations on decision-making by managers and health service practices.

\section{Strengths and limitations of the study}

This scoping review probably is the first broad study to map evidence on the application of metaevaluation in evaluative studies developed in PHC, providing comprehensive and detailed information on the potential and challenges of its use. The study met criteria for scoping reviews [82] and followed methodological references, checklists, and protocol [22].

Although the scoping review was conducted in line with the guidelines of the methodology, we still need to acknowledge some limitations. We did not evaluate quality of publications. However, this step is not essential due to the exploratory and descriptive nature of a scoping review. We did not include official government documents from gray literature. However, the search was performed to reach the highest number of publications regarding the topic. Even though databases for peer-reviewed publications and gray literature were included with no filter limits and a high-sensitivity search strategy was performed it is possible that there are other relevant studies in other databases that were not captured. It is possible researches on meta-evaluations existed under different terminologies that were not captured in the review. Nevertheless, we included DeCS and MeSH terms, and a wide range of keywords as well to help address this. We recommend future studies to conduct additional searches in those databases that were not captured by this study.

\section{Conclusions}

This scoping review mapped the application of meta-evaluation in evaluative studies developed in PHC. It was possible to consider that meta-evaluation lies in the ethical aspects of the evaluator and quality of evaluation while performing the study, when finished, or both times.

Results showed the potential and challenges of using meta-evaluation. This strategy may encourage evaluations, qualify its processes and results, support decision-making, improve of public policies and health practices, especially when it has formative, pedagogical, and democratic character. Metaevaluators are technically responsible for the evaluation process, in stimulating the action of those involved, and the decision-making capacity.

Some features of this study can be highlighted as recommendations: expansion of meta-evaluation in PHC to become a culture of both evaluation and meta-evaluation; use of evaluative standards (e.g., JCSEE) providing credibility and quality and enabling technical or instrumental values and interlocutions between individuals and knowledge construction; development of formative meta-evaluations with greater stakeholder involvement; and strengthening of meta-evaluations based on potentials of the activity, its challenges, and execution. 


\section{Abbreviations}

PHC: Primary Health Care

PRISMA - P: Preferred Reporting Items for Systematic review and Meta-Analysis Protocols.

PRISMA - ScR: PRISMA Extension for Scoping Reviews

JBI: Joanna Briggs Institute

JCSEE: Joint Committee on Standards for Educational Evaluation

PMAQ-AB: National Program to Improve Primary Care Access and Quality

\section{Declarations}

\section{Ethics approval and consent to participate}

Approved by research ethics committee of Onofre Lopes University Hospital - Federal University of Rio Grande do Norte (CAAE: 84537418.1.0000.5292).

\section{Consent for publication}

Not applicable.

\section{Availability of data and materials}

The datasets supporting the conclusions of this article are available through the detailed reference list.

\section{Competing interests}

All other authors declare they have no conflict of interest.

\section{Funding}

This work was supported by Department of Primary Care of the Ministry of Health (Brazil) and by National Council for Science and Technology Development (http://cnpq.br/), Process 207493 / 2014-6. The funders had no role in study design, data collection and analysis, decision to publish, or preparation of the manuscript.

\section{Authors' contributions}

SACU, OGBJ, CRDVS, RHL, and MFT planned the study. OGBJ and CRDVS performed study selection and data extraction, and SACU was the third reviewer. CRDVS, RHL, OGBJ, and CSM performed analysis and synthesis of results. All authors contributed to writing the manuscript. SACU, MFT and RAA critically reviewed the manuscript. All authors approved the final version of the manuscript. 


\section{Acknowledgements}

The authors would like to acknowledge colleagues at the Federal University of Rio Grande do Norte, Collective Health Department, who made important contributions to the work. We would like to express our sincere thanks to all four stakeholders in this study for their willingness to share their experiences.

The authors thank Probatus Academic Services for providing scientific language translation, revision, and editing.

\section{References}

1. Organization for Economic Co-operation and Development (OECD), and Statistical Office of the European Communities. Oslo Manual 2018: Guidelines for collecting, reporting and using data on innovation. OECD publishing, 2018.

2. Fortune $K$, Becerra-Posada F, Buss $P$, et al. Health promotion and the agenda for sustainable development, WHO Region of the Americas. Bull World Health Organ. 2018; 96(9):621-626. doi:10.2471/BLT.17.204404

3. Giovanella L, Mendoza-Ruiz A, Pilar ACA, et al. Sistema universal de saúde e cobertura universal: desvendando pressupostos e estratégias. Ciência \& Saúde Coletiva. 2018; 23(6): 1763-76. https://doi.org/10.1590/1413-81232018236.05562018.

4. Macinko J, Oliveira VB, Turci MA, et al. The influence of primary care and hospital supply on ambulatory care-sensitive hospitalizations among adults in Brazil, 1999-2007. American Journal of Public Health. 2011;101(10):1963-70. https://doi.org/10.2105/AJPH.2010.198887

5. Vieira-da-Silva LM, Furtado JP. A avaliação de programas de saúde: continuidades e mudanças. Cadernos de Saúde Pública. 2020; 36(9): e00237219. https://doi.org/10.1590/0102-311X00237219.

6. Malterud K, Aamland A, Iden KR. Small-scale implementation with pragmatic process evaluation: a model developed in primary health care. BMC Family Practice. 2018; 19(1): 1-10. https://doi.org/10.1186/s12875-018-0778-6

7. Boivin A, L'Espérance A, Gauvin FP, et al. 2018. Patient and public engagement in research and health system decision making: a systematic review of evaluation tools. Health Expectations. 2018; 21(6): 1075-84. https://doi.org/10.1111/hex.12804

8. Peters S, Bussières A, Depreitere B, et al. Facilitating Guideline Implementation in Primary Health Care Practices. Journal of Primary Care \& Community Health. 2020; 11: 2150132720916263. https://doi.org/10.1177/2150132720916263

9. Jacob S, Affodegon WS. Conducting quality evaluations: four generations of meta-evaluation. Spazio Filosofico. 2015; 13:165-75. http://www.spaziofilosofico.it/wpcontent/uploads/2015/02/Jacob-Affodegon.pdf

10. Stufflebeam DL. The Meta-evaluation imperative. American Journal of Evaluation. 2001; 22(2): 183209. https://doi.org/10.1177/109821400102200204 
11. Scriven M. Reflections. In: Alkin MC, editor. Evaluation Roots. Tracing theorists views and influences. Thousand Oaks: Sage Publications; 2004. p. 183-5.

12. Cooksy LJ, Caracelli VJ. Quality, context, and use: issues in achieving the goals of meta-evaluation. American Journal of Evaluation. 2005; 26(1): 31-42. https://doi.org/10.1177/1098214004273252

13. Furtado JP, Laperrière $H$. Parâmetros e paradigmas em meta-avaliação: uma revisão exploratória e reflexiva. Ciência \& Saúde Coletiva. 2012; 17(3): 695-705. https://doi.org/10.1590/S141381232012000300016.

14. Røsstad T, Garåsen H, Steinsbekk A, et al. Implementing a care pathway for elderly patients, a comparative qualitative process evaluation in primary care. BMC Health Services Research. 2015; 15(1): 1-9. https://doi.org/10.1186/s12913-015-0751-1

15. Alzaied TAM, Alshammari A. An evaluation of primary healthcare centers (PHC) services: the views of users. Health Science Journal. 2016; 10(2): 1-8.

16. Fausto MCR, Bousquat A, Lima JG, et al. Evaluation of brazilian primary health care from the perspective of the users: accessible, continuous, and acceptable? The Journal of Ambulatory Care Management. 2017; 40(2 Suppl): S60-S70. DOI: 10.1097/JAC.0000000000000183

17. Rifkin SB. Alma Ata after 40 years: primary health care and health for all-from consensus to complexity. BMJ Global Health. 2018; 3(Suppl 3): e001188. doi:10.1136/bmjgh-2018-001188

18. Peters MDJ, Godfrey C, Mclnerney P, et al. Chapter 11: Scoping reviews. In: Aromataris E, Munn Z, editor. JBI Manual for Evidence Synthesis. Adelaide: JBI. https:// synthesismanual.jbi.global, accessed 12 December 2020

19. Tricco AC, Lillie E, Zarin W, et al. 2018. PRISMA extension for scoping reviews (PRISMA-ScR): checklist and explanation. Annuals of Internal Medicine. 2018; 169: 467-73. DOI: 10.7326/M180850

20. Arksey H, O'Malley L. Scoping studies: towards a methodological framework. International Journal of Social Research Methodology. 2005; 8(1): 19-32. https://doi.org/10.1080/1364557032000119616

21. Levac D, Colquhoun H, O'Brien KK. Scoping studies: advancing the methodology. Implement Science. 2010; 5(1): 1-9. https://doi.org/10.1186/1748-5908-5-69

22. Bay Junior OG, Silva CRDV, Lopes RH, et al. Meta-evaluation of primary health care evaluative studies: Shopping Review protocol.2021. https://doi.org/10.6084/m9.figshare.14738037.v1

23. Shamseer $L$, Moher $D$, Clarke $M$, et al. Preferred reporting items for systematic review and metaanalysis protocols (PRISMA-P) 2015: elaboration and explanation. BMJ. 2015; 349: g7647. doi: https://doi.org/10.1136/bmj.g7647

24. Moher D, Liberati A, Tetzlaff J, et al. Preferred reporting items for systematic reviews and metaanalyses: the PRISMA statement. PLoS Medicine. 2009; 6(7): e1000097. https://doi.org/10.1371/journal.pmed.1000097

25. Sanders JR. Meta-evaluation of "the effectiveness of comprehensive, case management interventions: evidence from the National Evaluation of the Comprehensive Child Development 
Program". American Journal of Evaluation. 1999;20(3):577-582.

https://doi.org/10.1177/109821409902000316

26. Fonseca ACF. Avaliação para melhoria da qualidade da Estratégia Saúde da Família: um estudo de caso com foco na utilização dos resultados. Dissertação, Mestrado em Saúde Comunitária. Salvador: Universidade Federal da Bahia. 2009.

27. Figueiró AC, Hartz ZMA, Thuler LCS et al. Meta-evaluation of baseline studies of the Brazilian Family Health Strategy Expansion Project: a participatory and formative approach. Cadernos de Saúde Pública. 2010; 26: 2270-8. doi:10.1590/s0102-311x2010001200006

28. Léveillé S, Chamberland C. Toward a general model for child welfare and protection services: a metaevaluation of international experiences regarding the adoption of the Framework for the Assessment of Children in Need and Their Families (FACNF). Children and Youth Services Review. 2010; 32(7): 929-44. https://doi.org/10.1016/j.childyouth.2010.03.009

29. Natal S. Implantação e meta-avaliação, com foco na utilidade, das pesquisas financiadas pelo projeto Fortalecimento da Estratégia DOTS em Grandes Centros Urbanos com Alta Carga de Tuberculose no Brasil-Fundo Global, 2009-2011. Cadernos de Saúde Coletiva. 2012; 20 (2): $137-45$.

30. Dickson R. Conduct of a meta review of programme evaluations: a case study of the SEARCH Program. Tese, Doctoral of Philosophy. United Kingdon: Lancaster University. 2012.

31. Dias ALF. Meta-avaliação no contexto do Movimento Internacional Cidade Saudáveis: aplicação dos parâmetros e diretrizes do JCSEE (2011) e considerações de alguns aspectos éticos em questão. Tese, Doutorado em Ciências. Belo Horizonte: Fundação Oswaldo Cruz, Centro de Pesquisas René Rachou. 2012.

32. Nkwake, A. M., Trandafili, H., Hughey, J. Examining the Relationship Between Intentionality for Child Well-Being (CWB) and Program Outcomes in a Meta-Evaluation. Child Indicators Research. 2013; 6: 97-114. https://doi.org/10.1007/s12187-012-9160-8

33. Nickel DA, Natal S, Hartz ZMA et al. O uso de uma avaliação por gestores da atenção primária em saúde: um estudo de caso no Sul do Brasil. Cadernos de Saúde Pública. 2014; 30: 2619-2630. https://doi.org/10.1590/0102-311X00022314

34. Furtado JP. Por que avalio? Como avalio? O que aprendi ao avaliar? Revista Avaliação de Políticas Públicas. 2020; 3(17): 74-111.

35. Webster F, Christian J, Mansfield E, et al. Capturing the experiences of patients across multiple complex interventions: a meta-qualitative approach. BMJ Open. 2015; 5(9): e007664. http://dx.doi.org/10.1136/bmjopen-2015-007664

36. Conklin J, Farrell B, Ward N, et al. Developmental evaluation as a strategy to enhance the uptake and use of deprescribing guidelines: protocol for a multiple case study. Implementation Science. 2015; 10(91): 1-11. doi:10.1186/s13012-015-0279-0

37. Santos PF. Meta-avaliação do programa de melhoria do acesso e qualidade da atenção básica (PMAQ-AB) em Ubajara-CE: um estudo de caso. Dissertação (Mestrado em Saúde da Família). Sobral: Universidade Federal do Ceará. 2015. 
38. Kozica SL, Lombard CB, Harrison CL, et al. Evaluation of a large healthy lifestyle program: informing program implementation and scale-up in the prevention of obesity. Implementation Science. 2016; 11(1): 1-13. https://doi.org/10.1186/s13012-016-0521-4

39. Folli SPL. Análise do componente avaliativo do PMAQ na perspectiva de gestores e profissionais de saúde. Dissertação, Mestrado Profissional. Campinas: Universidade Estadual de Campinas. 2016.

40. Almeida CAL, Tanaka OY. 2017a. Meta-avaliação de uma avaliação participativa desenvolvida por gestores municipais de saúde com foco no padrão" Utilidade". Cadernos de Saúde Pública. 2017;33(2):e00105615. doi:10.1590/0102-311X0010561533

41. Almeida CAL, Tanaka OY. Meta-avaliação de um processo participativo no fortalecimento da gestão municipal. Revista de Saúde Pública. 2017; 51: 99. https://doi.org/10.11606/S15188787.2017051007047.

42. Oliveira MR. Meta-avaliação da AEPG - avaliação da execução de programas de governo: estudo de caso da Estratégia Saúde da Família. Dissertação, Mestrado em Políticas Públicas. Curitiba: Universidade Federal do Paraná. 2017.

43. Guerreiro CS, Ferrinho P, Hartz Z. Avaliação em saúde na República da Guiné-Bissau: uma metaavaliação do Plano Nacional de Desenvolvimento Sanitário. Saúde em Debate. 2018; 42(118): 54965. https://doi.org/10.1590/0103-1104201811801

44. Raifman J, Lam F, Madan Keller J, et al. How well are aid agencies evaluating programs? An assessment of the quality of global health evaluations. Journal of Development Effectiveness. 2018; 10(2): 277-89. https://doi.org/10.1080/19439342.2018.1452779

45. Uchoa SAC, Martiniano CS, Queiroz AAR, et al. Inovação e utilidade: avaliação externa do Programa Nacional de Melhoria do Acesso e da Qualidade da Atenção Básica. Saúde em Debate. 2018; 42(spe1): 100-13. https://doi.org/10.1590/0103-11042018S107

46. Barros LFR, Elliot LG. Meta-avaliação do relatório de avaliação da execução de programas de governo nº 8: Programa Saúde da Família. Revista Meta: Avaliação. 2018; 10: 197-224. http://dx.doi.org/10.22347/2175-2753v10i0.1933

47. Abreu, DMF. Usos e influências de uma avaliação de desempenho do Programa de Controle da Tuberculose em três municípios brasileiros. Tese, Doutorado em Saúde Pública. Rio de Janeiro: Escola Nacional de Saúde Pública Sergio Arouca, Fundação Oswaldo Cruz. 2018.

48. Joint Committee on Standards for Educational Evaluation (JCSEE). The program evaluation standards: a guide for evaluators and evaluation users: a guide for evaluators and evaluation users. Thousands Oaks, CA: Sage. 2011.

49. Pan American Health Organization. Renewing primary health care in the Americas: A position paper of the Pan American Health Organization/WHO. Washington, D.C.: PAHO; 2005. https://iris.paho.org/handle/10665.2/31083.

50. Giovanella L, Magalhães MH. Atenção primária à saúde. Rio de Janeiro: Editora FIOCRUZ. 2008.

51. Furtado JP, Vieira-da-Silva LM. A avaliação de programas e serviços de saúde no Brasil enquanto espaço de saberes e práticas. Cadernos de Saúde Pública. 2014; 30(12): 2643-55. 
https://doi.org/10.1590/0102-311X00187113

52. Silva GS, Fernandes DRF, Alves CRL. 2020. Avaliação da assistência à saúde da criança na atenção primária no Brasil: revisão sistemática de métodos e resultados. Ciência \& Saúde Coletiva. 2020; 25(8): 3185-3200. https://doi.org/10.1590/1413-81232020258.27512018

53. Oliveira LR, Passador CS. Ensaio teórico sobre as avaliações de políticas públicas. Cadernos EBAPE.BR. 2019; 17(2): 324-37. https://doi.org/10.1590/1679-395169657

54. Almeida PF, Giovanella L. Avaliação em atenção básica à saúde no Brasil: mapeamento e análise das pesquisas realizadas e/ou financiadas pelo Ministério da Saúde entre os anos de 2000 e 2006. Cadernos de Saúde Pública. 2008; 24(8): 1727-42. https://doi.org/10.1590/S0102$311 \times 2008000800002$

55. Hartz ZMA, Santos EM, Matida A. Promovendo e analisando o uso e a influência das pesquisas avaliativas. In: Hartz ZMA, Felisberto E, Vieira-da-Silva LMV, editor. Meta-avaliação da atenção básica à saúde: teoria e prática. Rio de Janeiro: Editora FIOCRUZ; 2008. p. 325-40.

56. Felisberto E, Freese E, Bezerra LCA et al. Análise da sustentabilidade de uma política de avaliação: o caso da atenção básica no Brasil. Cadernos de Saúde Pública. 2010; 26(6): 1079-95.

57. Figueiró AC, Thuler LC, Dias ALF. Padrões internacionais dos estudos de linha de base. In: Hartz ZMA, Felisberto E, Silva LMV, editor. Meta-avaliação da atenção básica à saúde: teoria e prática. Rio de Janeiro: Ed. Fiocruz; 2008. pp. 49-70.

58. Brasil. Programa Nacional de Melhoria do Acesso e Qualidade. Brasília: Ministério da Saúde.2012.

59. Macinko J, Harris MJ, Rocha MG. Brazil's National Program for Improving Primary Care Access and Quality (PMAQ): fulfilling the potential of the world's largest payment for performance system in primary care. The Journal of Ambulatory Care Management. 2017; 40(Suppl. 2): S4-S11. doi: 10.1097/JAC. 0000000000000189

60. Facchini LA, Tomasi E, Dilélio AS. Qualidade da atenção primária à saúde no Brasil: avanços, desafios e perspectivas. Saúde em Debate. 2018; 42 (spe1): 208-23. https://doi.org/10.1590/0103$11042018 S 114$

61. Silva DAJ, Tavares MFL. Ação intersetorial: potencialidades e dificuldades do trabalho em equipes da Estratégia Saúde da Família na cidade do Rio de Janeiro. Saúde em Debate. 2016; 40(111): 193205. https://doi.org/10.1590/0103-1104201611115

62. Samico I, Figueiró AC, Frias PG. Abordagens metodológicas na avaliação em saúde. In: Samico I, Felisberto E, Figueiró AC et al., editors. Avaliação em Saúde: bases conceituais e operacionais. Rio de Janeiro: MedBook; 2010. p. 15-28.

63. Figueiró AC, Felisberto E, Dubeux LS, et al. Avaliando as avaliações: meta-avaliação, uma introdução ao tema. In: Samico I, Felisberto E, Figueiró AC, editors. Avaliação em saúde: bases conceituais e operacionais. Rio de Janeiro: MedBook; 2010. p. 161-70.

64. Elliot LG, Orlando Filho O. Meta avaliações de políticas públicas do governo: o que revelam os relatórios de avaliação. São Paulo: Fundação Cesgranrio.2019. 
65. Kidder DP, Chapel TJ. CDC's program evaluation journey: 1999 to present. Public Health Reports. 2018; 133(4): 356-9. https://doi.org/10.1177/0033354918778034

66. Gill S, Kuwahara R, Wilce M. Through a culturally competent lens: why the program evaluation standards matter. Health Promotion Practice. 2016; 17(1): 5-8. https://doi.org/10.1177/1524839915616364

67. Montrosse-Moorhead B, Griffith JC. Toward the development of reporting standards for evaluations. American Journal of Evaluation. 2017; 38(4): 577-602. https://doi.org/10.1177/1098214017699275

68. Elliot LG. Meta-avaliação: das abordagens às possibilidades de aplicação. Ensaio: Avaliação e Políticas Públicas em Educação. 2011;19(73): 941-64. https://doi.org/10.1590/S010440362011000500011

69. Sturges KM, Howley C. Responsive meta-evaluation: a participatory approach to enhancing evaluation quality. American Journal of Evaluation. 2017; 38(1): 126-37. https://doi.org/10.1177/1098214016630405

70. Contandriopoulos AP. Avaliar a avaliação. In: Brousselle A, Champagne F, Contandriopoulos AP et al, editors. Avaliação: conceitos e métodos. Rio de Janeiro: Editora Fiocruz; 2016. p. 263-72.

71. Patton MQ. Pedagogy of evaluation. Hoboken: John Wiley \& Sons.2017.

72. Weiss $\mathrm{CH}$. The interface between evaluation and public policy. Evaluation. 1999; 5(4): 468-86. https://doi.org/10.1177/135638909900500408

73. Kirkhart KE. Reconceptualizing evaluation use: an integrated theory of influence. New Directions for Evaluation. 2000; 2000(88): 5-23. https://doi.org/10.1002/ev.1188

74. Henry GT, Mark M. Beyond use: understanding evaluation's influence on attitudes and actions. American Journal of Evaluation, 2003; 24(3): 293-314. https://doi.org/10.1177/109821400302400302

75. Patton MQ. Utilization-focused evaluation. 4rd ed. Thousand Oaks: Sage Publications;2008.

76. Stake RE. The art of case study research. Thousand Oaks: Sage Publications; 1995.

77. Cousins JB, Whitmore E. Framing participatory evaluation. New Directions for Evaluation. 1998; 1998 (80): 5-23. https://doi.org/10.1002/ev.1114

78. Scriven M. Evaluation thesaurus. $4^{\text {a }}$ ed. Newbury Park: Sage Publications. 1991.

79. Rodríguez-Campos L, Rincones-Gómez R. Collaborative evaluations: step-by-step. $2^{\mathrm{a}}$ ed. Stanford: Stanford University Press.

80. Fetterman DM, Campos LR, Zukoski AP. Collaborative, participatory, and empowerment evaluation: stakeholder involvement approaches. New York: The Guilford Press. 2017.

81. Cardoso GCP, Oliveira EAD, Casanova AO, et al. Participação dos atores na avaliação do Projeto QualiSUS-Rede: reflexões sobre uma experiência de abordagem colaborativa. Saúde em Debate. 2019; 43: 54-68. https://doi.org/10.1590/0103-1104201912004

82. Peters MDJ, Marnie C, Tricco AC, et al. Updated methodological guidance for the conduct of scoping reviews. JBI Evidence Synthesis Lippincott Williams and Wilkins. 2020;18(10):2119-2126. doi: 
Figures

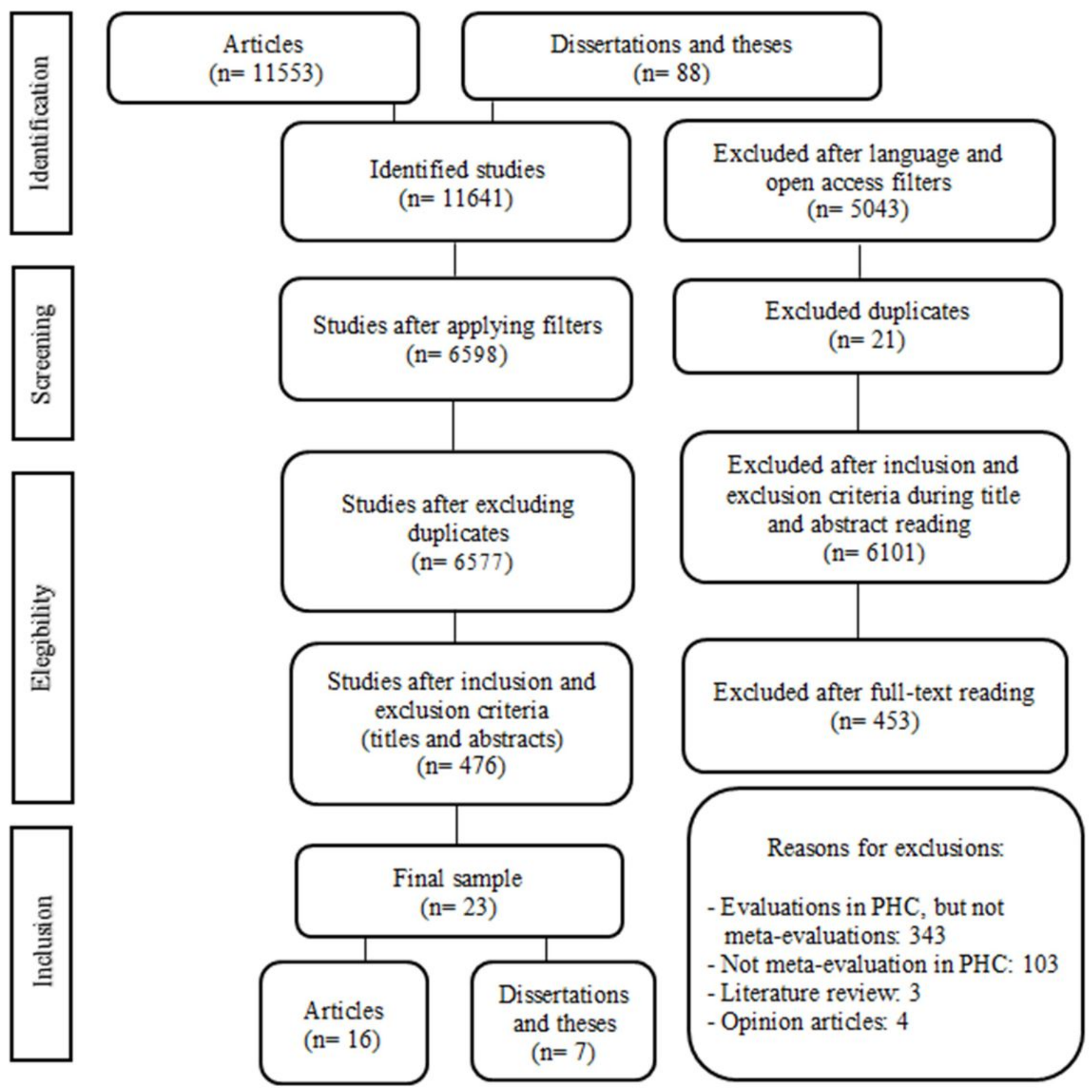

Figure 1

Flowchart of study selection process for scoping review adapted from Preferred Reporting Items for Systematic Review and Meta-Analyses (PRISMA-P). 


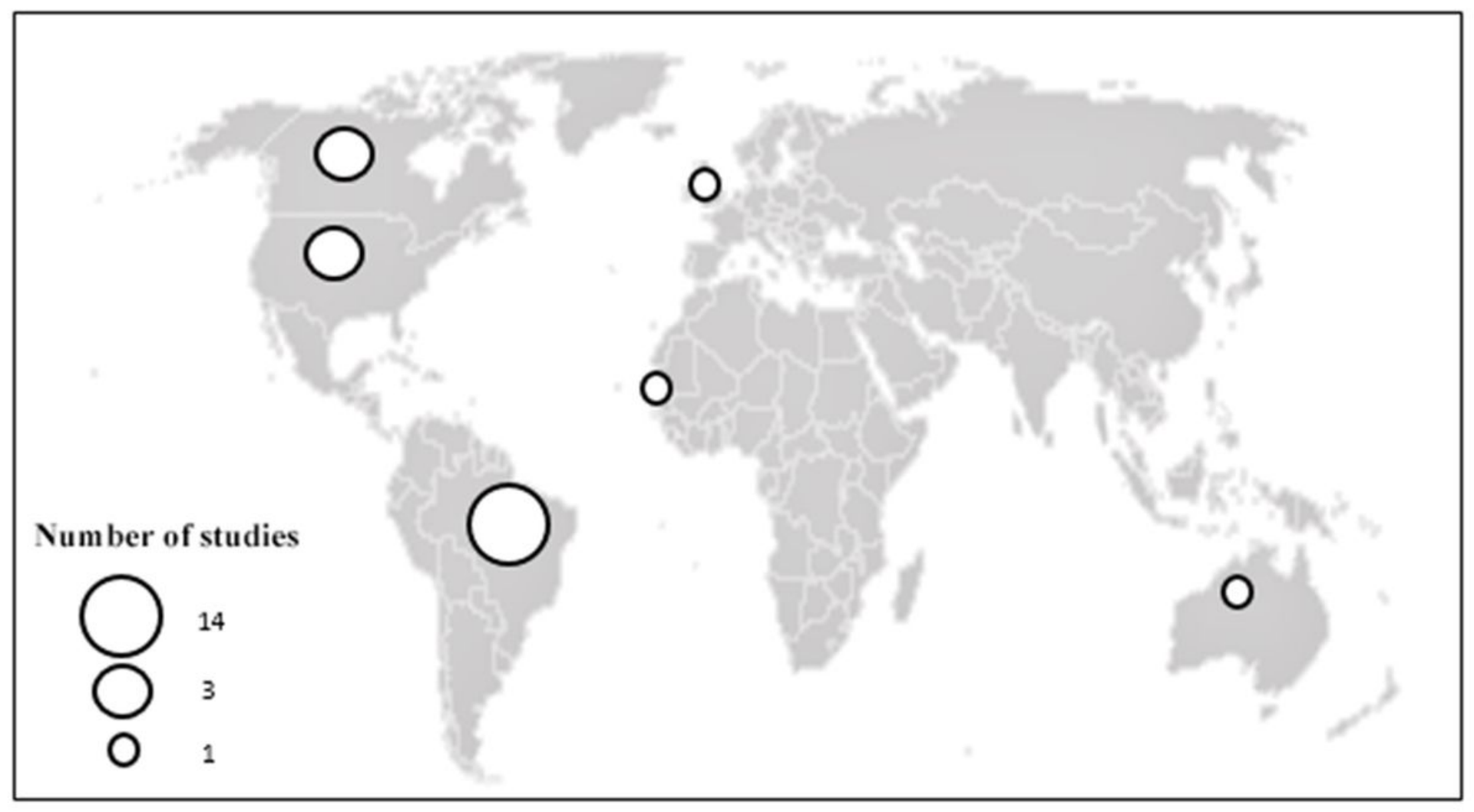

Figure 2

Quantitative geographic distribution of included studies.

\section{Supplementary Files}

This is a list of supplementary files associated with this preprint. Click to download.

- Additionalfile1.docx

- Additionalfile2.docx

- Additionalfile3PRISMAScRFillableChecklist.pdf 